\title{
Development in a Fragile Environment: The Case of Somalia
}

\author{
Mohamed Ali Arkow
}

Somalia is located in the Horn of Africa (see Figure 1). The total land area is 637,140 squarekilometres, most of which is rangeland. The Somali population is estimated at 7,595,000 (Immigration and Refugee Board Documentation Centre 1989). Rangelands are not suitable for agriculture because of low precipitation, extreme temperatures or soils that are shallow, rocky or infertile (Stoddart et al 1975).

\section{Land Use}

Nomadic pastoralism is the major landuse system in Somalia. Nomadism is a survival strategy in response to drought and a fragile environment that provides insufficient resources for the people and their herds. In some areas this system is supplemented by trading activities and opportunistic farming practices (Hoben 1988). Agropastoralism - which is a zero input, low output, shifting cultivation system-is practised in the southern interriverine zone, eastern Gedo, the coastal plains of central Somalia and the northwestern region of the country.

\section{Droughts}

Precipitation is the most important factor that determines the timing and duration of the Somali pastoralists' use of a particular rangeland. Rainfall is limited and unpredictable. Droughts occur frequently in Somalia and pastoralists (who comprise 75 percent of the population) consequently move their herds from one area to another to cope with rapidly changing environmental conditions. However, this traditional strategy was ineffective during the Sahel drought in the 1970s. According to Howze (1989), this drought was not particularly harsher than those in the past, but there were more people and animals in need of

Mohamed Ali Arkow is associated with the Centre for Refugee Studies. food and water. During the drought of 1973-74, the military government, with the assistance of the Soviet Union, airlifted thousands of starving people from the north and relocated them to three villages (Dujuuma, Sbalaale and Kunturwaarey) near the rivers of Shabeelle and Juba. Later, the relocated people were organized into agricultural cooperatives. This attempt to change nomadic pastoralists into farmers did not succeed. Two years after the relocation project, most of the males joined the unemployed population in the cities or emigrated to the Middle East, where the job market was booming.

\section{Environmental Migration}

Migration due to environmental degradation is not a new phenomenon in Somalia.In the mid-nineteenth century, the leaders of the Marehaan tribe realized that central Somalia could not provide enough water, forage and space for the increasing population and livestock. To find a more habitable environment, the council of chiefs decided to send exploratory teams to Jubaland in the south. The teams returned with information concerning the land and the tribes along the possible migration routes. The council of chiefs evaluated the reports and determined the number of people required to take Jubaland by force. They decided to move in waves. Each wave was comprised of a group of subclans. The first three waves reached Jubaland and began their conquest and expansion. However, subsequent waves of invaders were later discouraged by stories of malaria and other diseases in Jubaland. By the late nineteenth century, the Somalis in the north and northeast began leaving their territories because of deforestation and desertification. The northerners migrated to the Middle East, most of them to South Yemen. People from the northeast migrated to the south and settled in Mogadishu and Kismaayo.

\section{Development and Population Increase}

The Somali population was about 3.5 million in 1960 . By the late 1980 s the population had increased to seven million (Howze 1989). This rapid population growth was due to a high birth rate and low death rate. The birth rate is 47.9 births per 1,000 people, and the death rate is about 23.3 (Howze 1989). The difference of 24.6 is the natural increase for Somalia. The population of Somalia is increasing at a rate of a 2.46 percent per year, discounting the effect of the civil war. Using 1980 as the base year, the projected population of Somalia in the year 2000 (assuming a 2.5 percent rate of growth) will be $9,012,000$, and $18,904,000$ in 2030 (Howze 1989). This projection predicts that Somalia's population will increase 3.5 times in a fifty-year period.

To keep pace with this increase, the percapita economic development is supposed to grow 2.5 percent annually. To have a real growth, the economy's rate of growth must exceed 2.5 percent. Somalia will not exceed or even match its population growth with real economic development otherwise. Living standards in cities had slightly improved in the 1980s. However, the improvement was achieved by borrowing from developed nations and by incurring a huge national debt.

Soon after independence, Somalia began to promote national development. The first projects involved health and sanitation. Some diseases, such as smallpox, yellow fever, cholera and polio, were eradicated through immunization programs (Howze 1989). The military government's introduction and adoption of Somali as the official language of the country (using the Latin alphabet) facilitated the education of the rural population in health and disease prevention. By 1988 the death rate was reduced to half of what it was in 1960; but

Refuge, Vol. 13, No. 1 (April 1993) 
nomeaningful effort was madetoreduce the birth rate. Family planning programs were insignificant and had no impact on the population increase.

In contrast, a government-sponsored livestock development program had a far-reaching impact on the relationship between people and their environment. The program included animal health and water development. Diseases such as rinderpest and contagious bovine pleuropneumonia were eradicated through livestock immunization. Water development was a major component of the government's rural development programs. New wells and boreholes made remote areas more accessible to people and their herds, accelerating the process of sedentarization and creating many more villages. In a few years, large areas around the water sources were overstocked, overgrazed and finally denuded. Many people and animals perished as a result. In the following sections I will discuss central Somalia as typical rangeland, and how inappropriate technology led to more hunger and displacement of people rather than to development and prosperity.

\section{Central Somalia}

Central Somalia is located three to eight degrees north of the equator. The region is bordered on the east by the Indian Ocean, and to the west by Ogaden. Central Somalia encompasses an area of 160,000 square kilometres (Holt 1989), and includes the three administrative provinces of Mudug, Galgaduud and Hiiraan (see Figure 2).

The climate is arid to semiarid. The annual rainfall, which is erratic and uneven in distribution, varies from $100 \mathrm{~mm}$ in thenorth to $350 \mathrm{~mm}$ in the south. There are two wet and two dry seasons each year. The wet seasons are from March to June and from October to December. The dry seasons are from December to February and from July to September. The monthly mean maximum temperature is 29-32 degrees Celcius, and the monthly mean minimum is 20-24 Celcius.

Central Somalia is a relatively windy area with a strong northeast monsoon from November to March, and a southwest monsoon from May to October.
Wind causes most of the erosion in central Somalia, particularly in the agropastoral zone where clearing, weeding and grazing expose the soil.

Central Somalia is a featureless, flat plain. At the Ethiopian border, the elevation reaches $300-400 \mathrm{~m}$. The Shabeelle River flows south through a wide valley in the southwestern part of the region. Sand dunes, a distinct feature of the central rangelands, cover an area of about 4,000 square kilometres (Holt 1989). This means that 70 percent of Somalia's sand dunes are found in the central region. Sand dunes cause economic hardship in the region by covering wells, farms, houses, rangelands, and by blocking roads.

Soils in central Somalia are generally sandy, shallow and slightly alkaline (Herlocker 1989). The most common soil types are the Carro-cad (white soil) and Carro-guduud (red soil). The Carro-cad soil is calcareous and its topsoil is composed of fine sandy particles, organic matter and silt. Carrocad is a fertile soil in which cowpea is often cultivated. Because of the topsoil's composition, Carro-cad is susceptible to erosion. The Carro-guduud is orange-red in colour and less fertile than the white soil. It is shallow with limestone rocks covering the surface. In some areas, the red soil supports a very important, wild plant known as Yicib. Clay soil, which is common in the Shabeelle Valley of the Hiiraan province, is alkaline and saline. It is in poor condition due to overgrazing and overcultivation.

Groundwater is the main source of drinking water in the region. In the past, camel trains (Dhaan) were used to haul water. It used to be the men's responsibility tolead the Dhaan to distant places, sometimes through enemy territory, in order to bring back water for their families. This is still practised throughoutcentral Somalia, except along the east coast, where the government's water development programs were implemented during the 1970s and 1980s. Although the military government solved the problem of water shortage in the east, the subsequent concentrations of people and their cattle caused overgrazing of the rangeland and destruction of the fragile environment.

The population of central Somalia is difficult to estimate because the residents of central Somalia are also residents of western Somalia (Ogaden), but is approximately 1.5 million. Of this number, 750,000 could be considered permanent residents of the region (Howze 1989). Seventy percent of the population practise nomadic pastoralism and the remaining 30 percent are agropastoralists.

Central Somalia provides 25 percent of Somalia's livestockexport(Ministry of Livestock, Forest and Range 1988). The region has 42 percent of Somalia's goats, 23 percent of the sheep, 22 percent of the camels, and 11 percent of the cattle. Camels and goats are highly concentrated in 
the northern and western part of the region. Cattle are more common in the southern part, and sheep are the dominant animals in the coastal plains. While the movement of goats, cattle and sheep is limited within a radius of $20-30 \mathrm{kms}$, the camels are herded hundreds of kilometres.

Cowpeais the mostimportantcropin the agropastoral zone of the east. Other crops grown in the region include sorghum and maize. Mung beans were introduced in the 1980s. Cotton and sesame are increasingly becoming important cash crops in the south. Peanut is another minor crop. Sowing occurs just before the onset of the wet season. Agronomic practices, such clearing, weeding, sowing and harvesting, are done by hand, usingsmallaxesand short-handled hoes. In the Hiiraan province, the use of tractors has expanded in the last twenty years. Cleared vegetation is burned or used as fencing. Intercropping is a common practice in central Somalia. Melons are generally planted with other crops. Sorghum and cowpeas are usually planted together. The agropastoralists allow weeds to grow on the cultivated land during the dry season to savelabour and to make the soil less susceptible to wind erosion.

Trees are used for fuel and building purposes, although no attempt is made to plant them. The fuelwood is turned into charcoal and taken to Mogadishu by truck. This commercial activity is especially strong in the Hiiraan province. In $1988,20,000$ tons of charcoal per month was shipped from Jalalaksi district to Mogadishu (Holt 1989). In the two districts of Bulo Burti and Jalalaksi, trees are harvested faster than they can be replaced naturally. Around all watering points of central Somalia, the land is denuded of trees because the people rely totally on wood for cooking, heating and building.

In the southeastern part of central Somalia there is a species of fly known as Riibi. The species occupies an area about $500 \mathrm{~km}$ by $30-40 \mathrm{~km}$. The ecological factors that restrict the Riibi fly to this particular shrubland are unknown. The fly emerges nine days after the first rainfall of the rainy seasons and stays up to forty days, depending on the amount of rainfall. The pastoralists leave the area before the Ribiflies hatch and migrate to other parts of the country because the flies kill the animals bybleeding them. Also, the flies can carry camel trypanosomiasis. Sometimes the migrating tribes are forced to enter other tribes' territories, which can incite violent confrontations. The Riibi flies play a very important role in the protection of the rangelands. The presence of the flies gives the land a time to rest and the plants a chance to flower and grow without being grazed during a critical stage of their life cycles. When the outbreak of the flies ends and the pastoralists return with their herds, the plants are at a stage when they can tolerate the effect of grazing. In 1988 and 1989, I studied the spatial and temporal distribution of the flies. During the course of this study, the overwhelming majority of the pastoralists favoured the idea of total eradication of the flies.

Politically, it is to the advantage of any future government to do so in the country, but ecologically the elimination of the fly will have a far-reaching negative impact on the people of central Somalia and the country as a whole. Although the flies cause a temporary migration, their overall impact is positive for the people and their livestock. After all, nomadism is a land-use system based on migration.

\section{The Eradication of the Tsetse Flies}

The Riibiflies could not win the respect of the military government as an enemy worth fighting, but the tsetse flies did. In the mid 1980s, the Somali government, with the help of the British government, carried out a campaign of eradication
Fig. 2: Central Somalia

against tsetse flies using insecticides (Ministry of Livestock, Forest and Range 1988). The tsetse flies cause human and animal sleeping sickness (trypanosomiasis) in many parts of Africa. However, none of the four species of tsetse flies that exist in the country cause human sleepingsickness. The tsetse flies protected the natural environment along the rivers from an ever increasing number of animals without causing human trypanosomiasis. Since the problem facingSomalia was that of deforestation and desertification (not shortage of livestock), I believe it was wrong to destroy the only natural force in place to counter the trend of environmental deterioration. International experts blamed the Somali pastoralists for the declining productivity of the rangelands. In my view, it is debatable whether the pastoralists and their traditional land-use systems destroyed the land, or whether the projects implemented by experts made the environment more fragile and drought prone. 


\section{New Needs Without New Means}

Toassess the impact of any society on the environment, the formula I=PAT can be used as a guideline (Ehrlich and Ehrlich 1990).

$$
\mathrm{I}=\text { Impact; } \mathrm{P}=\text { Number of people }
$$

$A=$ Index of affluence or average consumption of resources per person

$\mathrm{T}=$ Technology orindex of the environmental disruptiveness of the technology used

Ehrlich and Ehrlich (1990) concluded that all nations, rich or poor, have a population problem. In rich nations, the rate of population growth is low, but the multipliers $A$ and $T$ are large. In contrast, the multiplier $P$ is very large in poor nations. The total impact on the environment can be decreased by lowering one of the three factors $(\mathrm{P}, \mathrm{A}$ or $\mathrm{T})$ as long as the other two do not increase to offset the difference.

Although I do not disagree with the Ehrlichs' conclusion, I do not believe that Somalia has an overpopulation problem. Somalia is the same size as Texas and has one-third of the population. In my view, Somalia is affected by a syndrome that could be called "new needs without new means." After years of European occupation, Somalis have learned to eat what Europeans eat and wear what Europeans wear. As a consequence, the average consumption of resources perperson has increased (multiplier A). The Western lifestyle wasintroduced intothe country, but Western know-how and technologies were not. Since Western technology was not available, the use of inappropriate technology (e.g., destruction of forests to obtain charcoal) was inevitable. After independence, Somalia became a net importer of Western products. To buy these products, Somalis had to sell their livestock. Selling livestock had an unexpected negative impact on the environment. Year after year, the imported products became more and more expensive, and Somalis had to sell more of their livestock to buy the same commodities. Consequently, the pastoralists had to increase their herds, causing the land to be overstocked and overgrazed.

In the future, the West has two choices in dealing with countries like Somalia. The first is to share technology with them. The second choice is to give them loans to buy Western products. Debt is already a serious problem for many African countries. Timberlake (1988) quoted a World Bank conclusion of 1984: "unless corrective measures are taken the external resource position of Sub-Saharan Africa is likely to become disastrous in the next few years." The former president of Tanzania, Julius Nyerere, put it in this way: "Africa's debt burden is intolerable. We cannot pay. You know it and all our other creditors know it. It is not a rhetorical question when I ask, should we really let our people starve so that we can pay our debts" (Timberlake 1988). Since these countries will not be able to pay their debts, recolonization could be an attractive alternative for the West. However, in the long run, this will make life harder for both sides.

\section{References}

Ehrlich, P.R., and Ann H.E. Ehrlich. 1990. Population Explosion. New York, New York: Simon and Schuster Inc.

Herlocker, D. 1989. "Range Survey and Development in the Central Rangelands of Somalia." Final report, unpublished.

Hoben, A. 1988. "The Political Economy of Land Tenure in Somalia." In Land Society in Contemporary Africa, edited by R.E. Downs and S.P. Reyna, 192-220. Hanover, New Hampshire: University Press of New England.

Holt, R.M. 1989. “Results of the Agropastoral Development Program in Central Somalia, 1985-1988." Final report, unpublished.

Howze, G. 1989. "Socio-Economic Survey of Somalia." Final report, unpublished.

Immigration and Refugee Board Documentation Centre. 1989. "Information Package on Somalia." Ottawa, Ontario: Immigration and Refugee Board Documentation Centre, January.

Ministry of Livestock, Forestry and Range. 1988. "Somali Livestock Statistics, 19881989." Mogadishu, Somalia. Unpublished.

Stoddart, L.A., A.D. Smith and T.W. Box. 1975. Range Management. New York, New York: McGraw-Hill.

Timberlake, L. 1988. Africa in Crisis. London, England: Earthscan Ltd.
Book Review

Nations of Immigrants: Australia, the United States, and International Migration

Oxford University Press, Melbourne, 1992 Edited by

Gary P. Freeman and James Jupp Reviewed by Nobuaki Suyama

Comparative immigration policy is in fashion. A comparative perspective always gives innovative, fresh viewpoints. This book explores the similarities and differences between Australia and the United States, two major immigrantreceiving countries whose official language is English. The title suggests that these countries are not only receivers of immigrants, but that they have been founded and developed by successive generations of immigrants. Although this concept has been popular in the United States, it is a relatively recent one in Australia. This is perhaps because everyone in the "melting pot" is no more or less American than anyone else, although it tooka long time to placeblack citizens on the same footing. On the other hand, Australia started as Britain's penal colony and retained British attitudes. Australians were predominantly "British" and non-British settlers were expected to conform.

The book consists of four parts: the politics regarding intake and control, the economics of immigration, settlement policy and newcomers' social integration. The chapters included are, on the whole, quite good and will be useful to students of comparative politics, immigration and ethnic affairs. However, it is a pity that with the exception of the chapter on microeconomic analysis, the others do not pursue an integrated comparison even though various contributors make occasional references to the other country. Even a chapter jointly written by an American and an Australian (Freeman and Betts) deals with each country's case under a separate heading. 